\title{
Community Structure and Abundance of Tintinnids in the Bay of Bengal During the Spring
}

\author{
${ }^{1,2}$ Huaxue Liu, ${ }^{1}$ Gang Li, ${ }^{1}$ Liangmin Huang, \\ ${ }^{3}$ Jianrong Huang, ${ }^{1}$ Zhixin Ke and ${ }^{1}$ Yehui Tan \\ ${ }^{1}$ Department of Marine Biology, \\ South China Sea Institute of Oceanology, Chinese Academy of Science, Guangzhou 510301, China \\ ${ }^{2}$ Department of Fishery Environment, South China Sea Fisheries Research Institute, \\ Chinese Academy of Fisheries Sciences, Guangzhou 510300, China \\ ${ }^{3}$ Faculty of Life Sciences, Sun Yat-Sen University, Guangzhou 510275, China
}

Received 2012-03-04, Revised 2012-07-13; Accepted 2012-07-19

\begin{abstract}
The Bay of Bengal (BoB) locates in eastern part of the northern Indian Ocean, with a unique inter-related oceanographic system due to the monsoon and enormous runoffs' supply. microbial food web often dominated the stratified Tropical Ocean, while few studies have been taken up to the tintinnids ciliates. Community structure and abundance of tintinnids were investigated in transact $10^{\circ} \mathrm{N}$ of the BoB during April 23 to May 2 of 2010. Discrete samples (for tintinnids and environment parameter analysis) were collected at various depths of $0,25,50,75,100,150$ and $200 \mathrm{~m}$ at each station. The tintinnids abundance vertically increased from surface water to maximal at the $75 \mathrm{~m}$, decreased thereafter to the 200 m layer. A total of 20 tintinnids species that belong to 16 genera. Undella ostenfedi was dominant species, followed by Eutintinnus fraknoii and Amphorella quadrilineata. Tintinnids abundance was positively correlated to chlorophyll a concentration $(\mathrm{p}<0.01)$, indicating the vertical distribution of the tintinnids community was regulated by available food resource.
\end{abstract}

Keywords: Tintinnids, Abundance, Community Structure, Bay of Bengal

\section{INTRODUCTION}

Tintinnids ciliates that have a lorica into which the ciliate cell can withdraw, occur in the worldwide oceans (Pierce and Turner, 1993; Dolan, 2000; Dolan et al., 2006). Many studies have provided quantitative data on tintinnids diversity of the world (Verity, 1985; Cariou et al., 1999; Thompson et al., 2004; Zhang et al., 2008). Biogeographic distributions of tintinnids related to hydrographics are well known for several oceanic provinces (Modigh et al., 2003; Thompson et al., 1999). The tintinnids are agreed to present as the tracers of upwelling, oceanic currents and water masses (Pierce and Turner, 1993; Krsinic and Grbec, 2006).

The BoB locates in eastern part of the northern Indian Ocean, with a unique inter-related oceanographic system due to the semi-annually reversed monsoon winds and enormous land-derived runoffs' supply (Jyothibabu et al., 2008). The BoB was conventionally referred as an oligotrophic water where nutrients (e.g., nitrate and phosphorus) were deplete (Narvekar and Kumar, 2006; Li et al., 2012) and solar radiation was low caused by cloudy days, restricting the phytoplankton growth (Madhupratap et al., 2003; Madhu et al., 2006). Moreover, microbial food web often dominated the stratified Tropical Ocean, microzooplankton may thus play important role in the BoB. Many studies of the BoB have focused on the hydrological features (Gomes et al., 2000), physical circulations (Schott and McCreary, 2001; Shankar et al., 2002) and phytoplankton characters (Li et al., 2012). However, few studies have been taken up to the tintinnids ciliates. In this study, vertical changes in community structure and ab.

Corresponding Author: Yehui Tan, Department of Marine Biology, South China Sea Institute of Oceanology,

Chinese Academy of Science, Guangzhou 510301, China 


\section{MATERIALS AND METHODS}

The tintinnids samples were collected during the BoB research cruise (April 23 to May 2, 2010), initiated by the South China Sea Institute of Oceanology, Chinese Academy of Science. Samples were collected from six sites along the transact $10^{\circ} \mathrm{N}$ of the BoB (Fig. 1), after the profiles of environmental factors being obtained as described in details by Li et al. (2012). The water column of the sampling area was severely stratified with the upper mixed layer of $\sim 75 \mathrm{~m}$ where the nutrientcline and maximal chlorophyll layers almost located (Li et al., 2012).

At each station, seven discrete tintinnids samples $(1 \mathrm{~L}$ for each) were collected at various depths of $0,25,50$, 75, 100, 150 and $200 \mathrm{~m}$, using a Rosette sampler fitted with 2.5-L Niskin Bottles. The collected water samples (1L) were fixed with Lugol's solution (final concentration of $1 \%$ ). Back in the laboratory, the samples were settled and concentrated to a volume of about $20 \mathrm{~mL}$. To examine tintinnids, the samples were thoroughly mixed and then $3 \mathrm{~mL}$ was dropped into a count chamber. Lorica of the tintinnids in the chamber was examined and counted under a Nikon stereomicroscope. Species were identified according to the shape of lorica with reference to Kofoid and Campbell (1929; 1939) and Carey (1992).

Pearson correlation analysis was applied to find the tintinnids community in relation to the environmental variables (SPSS 16.0 software).

\section{RESULTS}

A total of 20 tintinnids species belonging to 16 genera were identified in present study (Table 1). Maximum species number were found at B1 and B5 (10), followed by B4 and B6 (6); only 3 species presented at B3. Surface tintinnids abundance was only a few tens per liter, with the mean value of $<40$ ind $\mathrm{L}^{-1}$. Vertical distribution of tintinnids abundance coincided well with chl-a concentration (for details in $\mathrm{Li}$ et al., 2012), with the mean cell-density gradually increased from surface to DCM layer (except B2), then sharply decreased to the $200 \mathrm{~m}$ layers (Fig. 2).

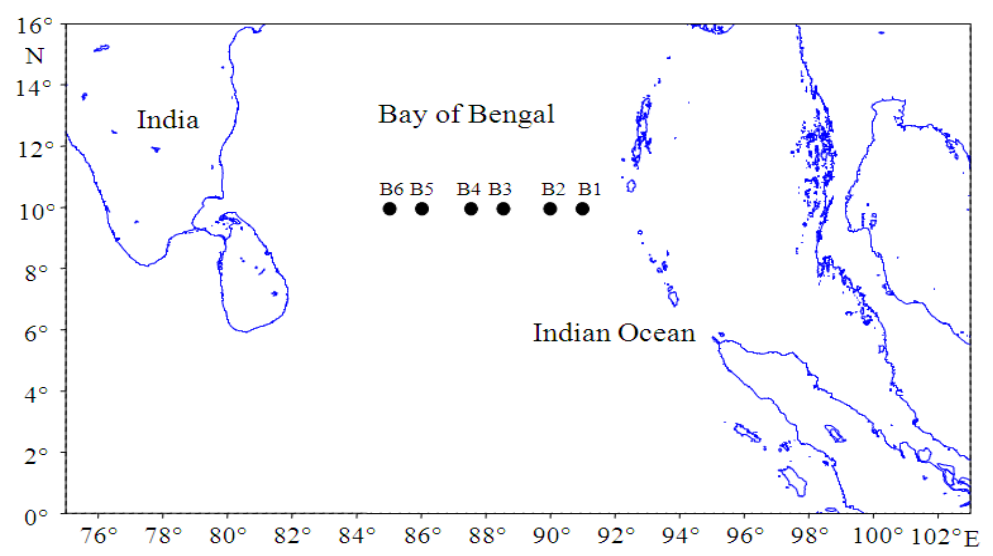

Fig. 1. Location of sampling site in the Bay of Bengal

\begin{tabular}{|c|c|c|c|c|c|c|}
\hline Depth/m & B1 & B2 & B3 & B4 & B5 & B6 \\
\hline 0 & $\begin{array}{l}\text { Marshallia aperta, } \\
\text { Undella ostenfedi* }\end{array}$ & Craterella retusa & nd & $\begin{array}{l}\text { Eutintinnus stramentus } \\
\text { Steenstrupiella gracilis }\end{array}$ & Eutintinnus fraknoii ${ }^{*}$ & Tintinnopsis schotti \\
\hline 25 & $\begin{array}{l}\text { Stenosemella inflate } \\
\text { Eutintinnus stramentus } \\
\text { Marshallia aperta }\end{array}$ & nd & Undella ostenfedi* & $\begin{array}{l}\text { Steenstrupiella gracilis } \\
\text { Undella ostenfed }{ }^{*}\end{array}$ & $\begin{array}{l}\text { Eutintinnus fraknoii* } \\
\text { Marshallia aperta } \\
\text { Rhabdonella sanyahensis }\end{array}$ & Undella ostenfedi* \\
\hline 50 & $\begin{array}{l}\text { Dadayiella ganymedes } \\
\text { Eutintinnus fraknoii* }\end{array}$ & nd & $\begin{array}{l}\text { Amphorella quadrilineata } \\
\text { Undella ostenfedi }\end{array}$ & $\begin{array}{l}\text { Eutintinnus fraknoii* } \\
\text { Undella ostenfedi* }\end{array}$ & $\begin{array}{l}\text { Amphorella quadrilineata } \\
\text { Epirhabdonella niei } \\
\text { Proplectella claparedei } \\
\text { Undella ostenfedi }\end{array}$ & $\begin{array}{l}\text { Amphorella quadrilineata } \\
\text { Undella ostenfedi* }\end{array}$ \\
\hline 75 & $\begin{array}{l}\text { Eutintinnus fraknoii* } \\
\text { Amphorella quadrilineata } \\
\text { Proplectella claparedei } \\
\text { Stenosemella inflata }\end{array}$ & $\begin{array}{l}\text { Dictyocysta reticulata } \\
\text { Salpingella minutissima } \\
\text { Salpingella minutissima }\end{array}$ & Eutintinnus fraknoii* & $\begin{array}{l}\text { Ormosella bresslaui } \\
\text { Salpingella attenuata }\end{array}$ & $\begin{array}{l}\text { Amphorella quadrilineata } \\
\text { Eutintinnus fraknoii* } \\
\text { Proplectella claparedei }\end{array}$ & $\begin{array}{l}\text { Salpingella attenuata } \\
\text { Salpingella cuneolata } \\
\text { Ormosella bresslaui }\end{array}$ \\
\hline 100 & nd & Salpingella minutissima & nd & nd & nd & $\begin{array}{l}\text { Salpingella cuneolata } \\
\text { Xystonellopsis heroica }\end{array}$ \\
\hline 150 & $\begin{array}{l}\text { Eutintinnus stramentus } \\
\text { Eutintinnus sp. }\end{array}$ & $\begin{array}{l}\text { Eutintinnus stramentus } \\
\text { Eutintinnus sp. }\end{array}$ & nd & nd & Salpingella attenuata & nd \\
\hline 200 & $\begin{array}{l}\text { Eutintinnus stramentus } \\
\text { Eutintinnus sp. }\end{array}$ & nd & nd & Steenstrupiella gracilis & nd & nd \\
\hline
\end{tabular}
nd: no detected 


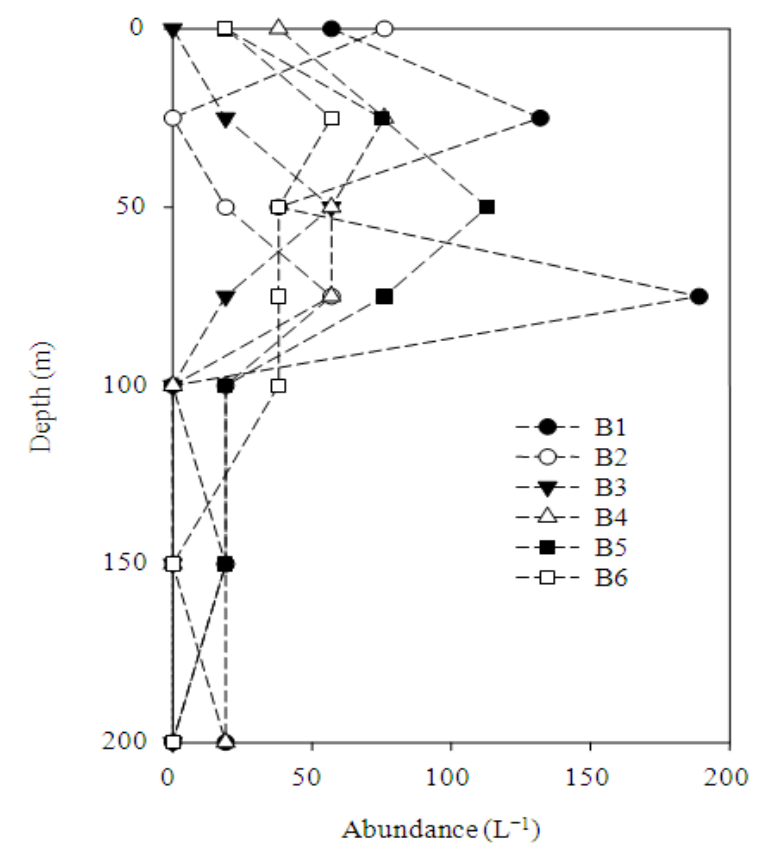

Fig. 2. Vertical distribution tintinnids abundance (ind $\mathrm{L}^{-1}$ )

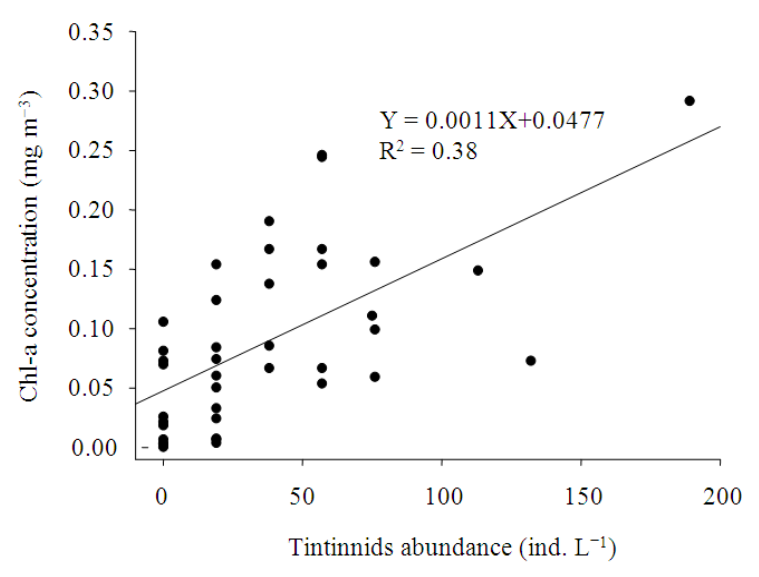

Fig. 3. Correlation between tintinnids abundance (ind. $\mathrm{L}^{-1}$ ) and Chl-a concentration $\left(\mathrm{mg} \mathrm{m}^{-3}\right)$ in the $\mathrm{BoB}$

Dominate species showed an obvious spatial difference in the BoB, with Undella ostenfedii found at most site expcept B2, followed by Eutintinnus fraknoii and Amphorella quadrilineata. Tintinnids community structure changed site by site, with Tintinnopsis schotti dominated the community at B1, E. fraknoii at B2, E. fraknoii and Proplectella claparedei at B5 and $U$. ostenfedii at B6. In particular the tintinnids abundance positively correlated to chl-a concentration $(\mathrm{P}<0.01)$ at each sampling layer (Fig. 3).

\section{DISCUSSION}

The activities of tintinnids such as grazing or excretion are probably much less important than those of the naked oligotrich taxa in marine ecosystems, since they merely account for low proportion $(<10 \%$ of cell numbers or biomass) of the ciliate community (Dolan and Marrase, 1995; Dolan, 2000). Furthermore, the tintinnids may play a relatively minor role in e.g., carbon flux or nutrient regeneration; however, they are ideal organisms (easily be detected) to mark the changes in species structure or community of microzooplankton (Thompson et al., 1999; Dolan, 2000). Krsinic and Grbec (2006) thus suggested that ingression of water masses from the Ionian Sea and formation of cyclonic gyre was important in determining the horizontal distributions of tintinnids in the south Adriatic. In this study, tintinnids abundance and integrated Chl-a concentration at B1 was higher than B2. Nevertheless, B1 (low temperature and high salinity) and B2 (high temperature and low salinity) showed differential environment characters (Li et al., 2012). Different environments resulted in different tintinnids compositions, in turns, indicated the responses of that the tintinnids to the environmental changes.

Chl-a concentrations and primary productivity values were low in present study (Li et al., 2012; Liu et al., 2011), as a consequence, tintinnids abundance was relative low (Fig. 2). Due to the weaker wind force and relative warmer climate that depress the exchanges of the nutritious deeper water with the surface water, the $\mathrm{BoB}$ is considered as a region of low biological productivity (Gomes et al., 2000; Kumar et al., 2002; 2007).

Dolan et al. (2002) postulated that the tintinnids diversity reflected the resource diversity more closely than the competitive interactions or predation. The abundance of tintinnids positively correlated to chl-a concentration in present study, this could be explained by their feeding on phytoplankton (especially pico and nanophytoplankton), indicated the phytoplankton biomass regulated the ciliates abundance in the BoB.

\section{CONCLUSION}

Surface tintinnids abundance was only a few tens per liter and the mean cell-density gradually increased from surface to DCM layer (except B2), then sharply decreased to the $200 \mathrm{~m}$ layers. Undella ostenfedii was the dominate species at most site in the BoB. Tintinnids abundance was positively correlated to chlorophyll a concentration, 
indicating the vertical distribution of the tintinnids community was regulated by available food resource.

\section{ACKNOWLEDGMENT}

This research was supported by National Nature Science Foundation of China (41130855). Special Project of the Social Commonwealth Research of the National Science Research Institute (South China Sea Fisheries Research Institute, Chinese Academy of Fishery Sciences) (No. 2011TS06).

\section{REFERENCES}

Carey, P.G., 1992. Marine Interstitial Ciliates: An Illustrated Key. 1st Edn., Springer, London, ISBN10: 0412406101, pp: 368.

Cariou, J.B., J.R. Dolan and S. Dallot, 1999. A preliminary study of tintinnid diversity in the NW Mediterranean Sea. J. Plankton Res., 21: 1065-1075. DOI: 10.1093/plankt/21.6.1065

Dolan, J.R. and C. Marrase, 1995. Planktonic ciliate distribution relative to a deep chlorophyll maximum: Catalan Sea, N.W. Mediterranean, June 1993. Deep Sea Res. Part I: Oceanogr. Res. Papers, 42: 19651987. DOI: 10.1016/0967-0637(95)00092-5

Dolan, J.R., 2000. Tintinnid ciliate diversity in the Mediterranean Sea: longitudinal patterns related to water column structure in late spring-early summer. Aquatic Microbiol. Ecol., 22: 69-78. DOI: 10.3354/ame022069

Dolan, J.R., H. Claustre, F. Carlotti, S. Plounevez and T. Moutin, 2002. Microzooplankton diversity: Relationships of tintinnid ciliates with resources, competitors and predators from the Atlantic Coast of Morocco to the Eastern Mediterranean. Deep-Sea Res. Part I: Oceanogr. Res. Papers, 149: 1217-1232. DOI: 10.1016/S0967-0637(02)00021-3

Dolan, J.R., S. Jacquet and J.P. Torreton, 2006. Comparing taxonomic and morphological biodiversity of tintinnids (planktonic ciliates) of New Caledonia. Limnol. Oceanogr., 51: 950-958. DOI: 10.4319/1o.2006.51.2.0950

Gomes, H.R., J.I. Goes and T. Saino, 2000. Influence of physical processes and freshwater discharge on the seasonality of phytoplankton regime in the Bay of Bengal. Continental Shelf Res., 20: 313-330. DOI: 10.1016/S0278-4343(99)00072-2
Jyothibabu, R., N.V. Madhu, P.A. Maheswaran, K.V. Jayalakshmy and K.K.C. Nair et al., 2008. Seasonal variation of microzooplankton $(20-200 \mu \mathrm{m})$ and its possible implications on the vertical carbon flux in the western Bay of Bengal. Continental Shelf Res., 28: 737-755. DOI: 10.1016/j.csr.2007.12.011

Kofoid, C.A. and A.S. Campbell, 1929. A conspectus of the marine and freshwater ciliata belonging to the suborder Tintinoinea, with descriptions of new species principally from the agassiz expedition to the eastern tropical pacific. University of Califfornia Press, Califfornia.

Kofoid, C.A. and A.S. Campbell, 1939. The Ciliata: The Tintinnoinea. 1st Edn., Printed for the Museum, Cambridge, pp: 473.

Krsinic, F. and B. Grbec, 2006. Horizontal distribution of tintinnids in the open waters of the south Adriatic (Eastern Mediterranean). Sci. Mar., 70: 77-88. DOI: 10.3989/scimar.2006.70n177

Kumar, S.P., M. Nuncio, N. Ramaiah, S. Sardesai and J. Narvekar et al., 2007. Eddy-mediated biological productivity in the Bay of Bengal during fall and spring intermonsoons. Deep-Sea Res. Part I: Oceanographic Res. Papers, 154: 1619-1640. DOI: 10.1016/j.dsr.2007.06.002

Kumar, S.P., P.M. Muraleedharan, T.G. Prasad, M. Gauns and N. Ramaiah et al., 2002. Why is the Bay of Bengal less productive during summer monsoon compared to the Arabian Sea? Geophys. Res. Lett., 29: 2235-2235. DOI: 10.1029/2002GL016013

Li, G., Z. Ke, Q. Lin, G. Ni and P. Shen et al., 2012. Longitudinal patterns of spring-intermonsoon phytoplankton biomass, species compositions and size structure in the Bay of Bengal. Acta Oceanol. Sinica, 31: 121-128.

Liu, H.X., Z.X. Ke, X.Y. Song, Y.H. Tan and L.M. Huang et al., 2011. Primary production in the Bay of Bengal during spring intermonsoon period. Acta Ecol. Sinica, 31: 7007-7012.

Madhu, N.V., R. Jyothibabu, P.A. Maheswaran, V.J. Gerson and T.C. Gopalakrishnan et al., 2006. Lack of seasonality in phytoplankton standing stock (chlorophyll a) and production in the western Bay of Bengal. Continental Shelf Res., 26: 1868-1883. DOI: 10.1016/j.csr.2006.06.004

Madhupratap, M., M. Gauns, N. Ramaiah, S.P. Kumar and P.M. Muraleedharan et al., 2003. Biogeochemistry of the Bay of Bengal: Physical, chemical and primary productivity characteristics of the central and western Bay of Bengal during summer monsoon 2001. Deep-Sea Res. Part II: Topical Stud. Oceanography, 50: 881-886. DOI: 10.1016/S0967-0645(02)00611-2 
Modigh, M., S. Castaldo, M. Saggiomo and I. Santarpia, 2003. Distribution of tintinnid species from $42^{\circ} \mathrm{N}$ to $43^{\circ} \mathrm{S}$ through the Indian Ocean. Hydrobiologia, 503: 251-262.

Narvekar, J. and S.P. Kumar, 2006. Seasonal variability of the mixed layer in the central Bay of Bengal and associated changes in nutrients and chlorophyll. Deep-Sea Res. Part I: Oceanographic Res. Papers, 53: 820-835. DOI: 10.1016/j.dsr.2006.01.012

Pierce, R.W. and J.T. Turner, 1993. Global biogeography of marine tintinnids. Marine Ecol. Prog. Ser., 94: 1126. DOI: $10.3354 /$ meps094011

Schott, F.A. and J.P. Jr. McCreary, 2001. The monsoon circulation of the Indian Ocean. Progress Oceanogr., 51: 1-123. DOI: 10.1016/S0079-6611(01)00083-0

Shankar, D., P.N. Vinayachandran and A.S. Unnikrishnan, 2002. The monsoon currents in the north Indian Ocean. Progress Oceanogr., 52: 63-120. DOI: 10.1016/S0079-6611(02)00024-1
Thompson, G.A., 2004. Tintinnid diversity trends in the southwestern Atlantic Ocean (29 to $\left.60^{\circ} \mathrm{S}\right)$. Aquatic Microbial. Ecol., 35: 93-103. DOI: 10.3354/ame035093

Thompson, G.A., V.A. Alder, D. Boltovskoy and F. Brandini, 1999. Abundance and biogeography of tintinnids (Ciliophora) and associated microzooplankton in the Southwestern Atlantic Ocean. J. Plankton Res., 21: 1265-1298. DOI: 10.1093/plankt/21.7.1265

Verity, P.G., 1985. Grazing, respiration, excretion and growth rates of tintinnids. Limnol. Oceanogr., 30: 1268 -1282. DOI: 10.4319/10.1985.30.6.1268

Zhang, C., W. Zhang, T. Xiao, R. Lu and S. Sun et al., 2008. Meso-scale spatial distribution of large tintinnids in early summer in southern Yellow Sea. Chinese J. Oceanol. Limnol., 26: 81-90. 